\title{
Endophytic fungi in Canada wild rye in natural grasslands
}

\author{
MARY ANN VINTON, EMILY S. KATHOL, KENNETH P. VOGEL, AND ANDREW A. HOPKINS
}

Authors are associate professor, Department of Biology and Program for Environmental Science, Creighton University, Omaha, Nebr. 68178; graduate research assistant, Institute for Environmental Studies, University of Wisconsin, Madison, Wis. 53706; research leader, USDA-ARS and adjunct professor, Agronomy Department, University of Nebraska, Lincoln, Nebr. 68583; and research leader, Forage Biotechnology Group, Noble Foundation Inc., Ardmore, Okla. 73401.

\begin{abstract}
Some grasses harbor endophytic fungi living in intercellular spaces in the leaves, stems and reproductive organs. The fungi can dramatically affect the physiology and ecology of plants. For example, fungi may produce toxins that deter herbivores and they may alter the water status of the plant to increase drought tolerance. The distribution of fungal infection in natural plant populations is unknown for many host species. We investigated the occurrence of endophytic fungi in Elymus canadensis $\mathrm{L}$. (Canada wild rye) from 13 remnant prairie sites in the midwest and 23 sites in the southern Great Plains. Collections of plant tissue came from Nebraska, Kansas, Minnesota, Iowa, Missouri, Illinois, Oklahoma, and Texas. All midwest plants were grown in a common garden site in eastern Nebraska. Seeds collected from Oklahoma and Texas accessions were planted in the greenhouse. At least 3 tillers from 2 plants of each accession were screened for endophytes, using light microscopy. The endophytic fungus was found in seed of all accessions and in plants from all but 4 accessions. The functional significance of the fungus is unclear, but it may affect plants by enhancing productivity or deterring herbivores. The widespread occurrence of endophytic fungi in natural populations of $E$. canadensis suggests that the plant-fungal association may be long-standing and important in the evolution and success of this native prairie species.
\end{abstract}

Key Words: Elymus canadensis, Epichlo typhina, Neotyphodium, geographical pattern, mutualism, tallgrass prairie

Many grasses are infected by clavicipitaceous fungal endophytes that grow in the intercellular portions of the stems, leaves and reproductive organs. The fungi are often asymptomatic and are known to occur in all grass subfamilies and in most of the large grass genera (Clay 1990). Much of the research on fungal endophytes concerns the incidence and the effects of the infection in the important forage and turfgrass genera, Festuca (fescue) and Lolium (ryegrass). Endophytic fungi in agronomic Festuca and Lolium decrease the palatability of the grass to insect and mammalian herbivores and can cause toxicosis in livestock due to fungal and possibly, plant, production of alkaloids (Bacon et al. 1977, Funk et al. 1983 and Clay et al. 1985). The fungi can also

We are grateful to Kimberly Woods, Erin Goergen, Dan Deatsch, Jayme Horning and Renae Schmitt for field and lab assistance and to Dr. Nick Hill at the University of Georgia for performing the alkaloid analysis and immunoblot assay. This work was supported by the Clare Boothe Luce endowment at Creighton University and by the NSF Long Term Ecological Research Program (DEB 96328510) at Konza Prairie Research Natural Area.

Manuscript accepted 2 Sept. 2000.

\section{Resumen}

Algunos zacates albergan hongos endofiticos que viven en los espacios intracelulares de las hojas, tallos y órganos reproductivos. Los hongos pueden afectar dramáticamente la fisiología y ecología de las plantas. Por ejemplo, el hongo puede producir toxinas que desalientan a los herbívoros y ellos pueden alterar el estado hídrico de la planta para incrementar la tolerancia a sequía. La distribución de la infección fungal en poblaciones de plantas naturales es desconocida para muchas de las especies hospederas. Investigamos la ocurrencia de hongos endofiticos en Elymus canadensis L. (Canada wild rye) en 13 sitios de pradera en el medio oeste y en 23 sitios en las Grandes Planicies del Sur. Colecciones de tejidos de plantas arribaron de Nebraska, Kansas, Minnesota, Iowa, Missouri, Illinois, Oklahoma, and Texas. Todas las plantas provenientes del medio oeste se cultivaron en un sitio de jardín común en el este de Nebraska. Las semillas colectadas de las entradas de Oklahoma and Texas se plantaron en invernadero. Al menos 3 hijuelos de dos plantas de cada entrada se inspeccionaron mediante luz microscópica para determinar los endófitos. El hongo endófito se encontró en las semillas de todas las entradas $y$ en plantas de todas menos 4 entradas. El significado funcional del hongo no es claro, pero puede afectar las plantas aumentando su productividad o desalentando a los herbívoros. La ocurrencia tan amplia y dispersa de los hongos endofiticos en las poblaciones naturales de $E$. Canadiensis sugiere que la asociación planta-hongo puede ser importante en la evolución y éxito de esta especie nativa de las pradera

enhance the growth and productivity of the plant (Belesky and Fedders 1995), especially under drought conditions (Arachevaleta et al. 1989). Bacon (1995) and Ball et al. (1993) reviewed the history of the endophyte, Neotyphodium coenophialum, (formerly known as Acremonium coenophialum) in tall fescue in which the particularly hardy, disease-resistant and (unknown at the time) endophyte-infected cultivar, KY 31, was widely adopted throughout the United States from the 1940's onward. The existence and role of the fungal endophyte in KY 31 was documented in the late 1970's, when reports of livestock disorders began to accumulate (Bacon et al. 1977, Hoveland et al. 1980).

Recently, efforts to characterize the evolution and ecology of the fungal-plant relationship in natural grass endophytes have been undertaken - for example, is the association mutualistic and how might such an arrangement have arisen? White (1988) presented some hypotheses about the origin and evolution of some of the known plant-fungal associations. In some grasses, the 
endophytic fungus forms external fruiting structures (stromata) that prevent the grass from flowering - thus the fungus completes its sexual lifecycle at the expense of the host plant. Since the host incurs some negative impacts, this type of association is pathogenic and White (1988) called this a "Type 1" association. In "Type 3" associations, stromata have never been observed and the fungus appears to spread asexually, by growing into the embryo and dispersing with the seed, and also spreading with clonal growth of the grass. In this type of association, the fungus appears to have positive effects on the plant, by protecting it from herbivores and enhancing growth. However it should be noted that the classification of many endophyte infections as mutualisms has been heavily influenced by results from a few agronomic species. Recent results from native species have emphasized the variety of negative, neutral and positive plant consequences (other than release from herbivory) that can result from endophyte infection (Saikkonen et al. 1998, 1999). White (1988) further defines a Type 2 association, in which only $1-10 \%$ of the individual plants within an infected population produce stromata, even though $50-75 \%$ of the individuals may harbor the fungus. The fungal-plant association in Elymus canadensis is thought to be Type 2 (White 1988) but more field observations are necessary to quantify the frequency and type of fungal infection in this species.

The frequency and type of infection of endophytic fungi throughout the range of a potential host are well-known for only a few host species. These species tend to be forage species tested because of the potential for causing livestock toxicity. The distribution of these species has been extensively influenced by human land management and planting. Studies on the extent of the fungal distribution within and between natural populations may shed light on the origin and evolution of the plant-fungus association. In one of the most complete studies to date on a natural grass population and its endophytes, Schulthess and Faeth (1998) found high seasonal and spatial variability in Neotyphodium starrii in the grass Festuca arizonica.

Our goal was to describe the extent of endophytic fungal infection in Elymus canadensis in the central grassland region of the United States. E. canadensis is a native, cool-season bunchgrass, abundant in tall and mixed-grass prairies. This species is known to harbor endophytic fungi, and a previous study of herbarium specimens suggested that fungi are present in about $60 \%$ of the E. canadensis individuals in North America (White 1987). The fungus is similar to Epichloë typhina (Ascomycetes), but because the sexual structures are seldom observed, it has been placed, along with other related grass endophytes into the genus Neotyphodium (Glenn et al. 1996). We screened fresh plant tissue collected from 2 sites in Nebraska and Kansas for the presence of Neotyphodium. We also screened tissue from a common garden that had been established from seed from 11 remnant tallgrass prairies in Nebraska, Iowa, Minnesota, Missouri, and Illinois, and from greenhouse grown plants derived from seed collected from Oklahoma and Texas.

\section{Materials and Methods}

Collections of E. canadensis germplasm ranged from Minnesota to Texas, with 8 states represented (Fig. 1). Sites consisted of virgin tallgrass prairie from roadsides, cemeteries, railroad right of ways or preserves, pastures, or farmland which had reverted to rangeland (Table 1). Some of the tissue was collected from a common garden site, which harbored plant accessions from 11 different sites (Sites 1-11 in Table 1) and some of the tissue was collected directly from the sites.

The common garden site near Mead, Nebr. $\left(41.2^{\circ} \mathrm{N}, 96.5^{\circ} \mathrm{W}\right)$ was established in the following way. E. canadensis seed was

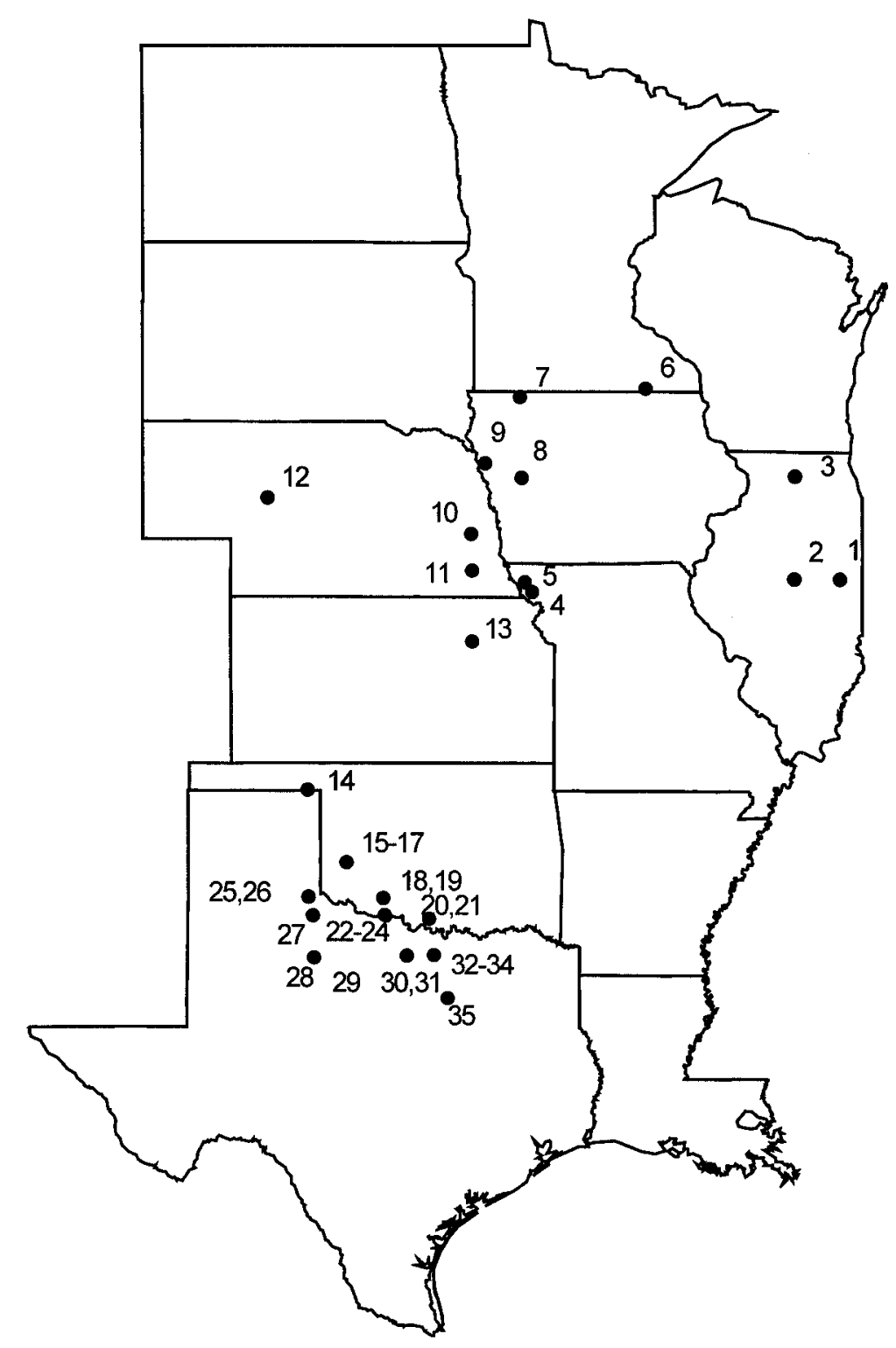

Fig. 1. Location of Elymus canadensis collection sites. 
Table 1. Sites where germplasm of Elymus canadensis was collected and screened for the presence of a fungal endophyte. See Figure 1 for numbered site locations. Plant material from sites 1-11 and 14-35 was propagated in a greenhouse and transplanted into a common garden before endophyte screening took place. Tillers and seeds from sites 12-13 were collected directly from the site and screened for endophyte presence.

\begin{tabular}{|c|c|c|c|c|c|}
\hline Site Number & Location & Nearest Town & Longitude/Latitude & $\begin{array}{c}\text { Endophyte } \\
\text { In Seed }\end{array}$ & $\begin{array}{c}\text { Endophyte } \\
\text { In Plant }\end{array}$ \\
\hline 1 & Loda Cemetery & Loda, Ill & $88.05 \mathrm{~W} / 40.32 \mathrm{~N}$ & + & + \\
\hline 2 & McLean Right of Way & Danvers, Ill & $89.10 \mathrm{~W} / 40.32 \mathrm{~N}$ & + & + \\
\hline 3 & Beach Cemetery & Rockford, Ill & $89.08 \mathrm{~W} / 42.08 \mathrm{~N}$ & + & + \\
\hline 4 & Holt County & Mound City, Mo & $95.12 \mathrm{~W} / 40.08 \mathrm{~N}$ & + & + \\
\hline 5 & Atchison County Roadside & Rockport, Mo & $95.29 \mathrm{~W} / 40.25 \mathrm{~N}$ & + & + \\
\hline 6 & Iron Horse & Hayfield, Minn & $92.50 \mathrm{~W} / 43.55 \mathrm{~N}$ & + & + \\
\hline 7 & Compass & Worthington, Minn & $95.40 \mathrm{~W} / 43.40 \mathrm{~N}$ & + & + \\
\hline 8 & Willow Township Cemetery & Charter Oak, Ia & $95.36 \mathrm{~W} / 42.04 \mathrm{~N}$ & + & + \\
\hline 9 & Sioux City & Sioux City, Ia & $96.20 \mathrm{~W} / 42.28 \mathrm{~N}$ & + & + \\
\hline 10 & Narodni Hrbitior Cemetery & Touhy, Nebr & $96.52 \mathrm{~W} / 41.08 \mathrm{~N}$ & + & + \\
\hline 11 & Nine Mile Prairie & Lincoln, Nebr & $96.50 \mathrm{~W} / 40.45 \mathrm{~N}$ & + & + \\
\hline 12 & Vinton Ranch & Mullen, Nebr & $101.20 \mathrm{~W} / 41.70 \mathrm{~N}$ & + & + \\
\hline 13 & Konza Prairie & Manhattan, Kans & $96.50 \mathrm{~W} / 39.20 \mathrm{~N}$ & + & + \\
\hline 14 & OKCS-38 & Beaver, Okla & $100.29 \mathrm{~W} / 36.36 \mathrm{~N}$ & + & + \\
\hline 15 & OKCS-30 & Elk City, Okla & $99.40 \mathrm{~W} / 35.15 \mathrm{~N}$ & + & + \\
\hline 16 & OKCS-26 & Mangum, Okla & $99.46 \mathrm{~W} / 35.03 \mathrm{~N}$ & + & + \\
\hline 17 & OKCS-29 & Erick, Okla & $99.54 \mathrm{~W} / 35.05 \mathrm{~N}$ & + & + \\
\hline 18 & OKCS-23 & Snyder, Okla & $98.55 \mathrm{~W} / 34.48 \mathrm{~N}$ & + & + \\
\hline 19 & OKCS-20 & Snyder, Okla & $98.55 \mathrm{~W} / 34.48 \mathrm{~N}$ & + & + \\
\hline 20 & OKCS-16 & Waurika, Okla & $98.05 \mathrm{~W} / 34.09 \mathrm{~N}$ & + & + \\
\hline 21 & OKCS-7 & Lone Grove, Okla & $97.16 \mathrm{~W} / 34.10 \mathrm{~N}$ & + & + \\
\hline 22 & OKCS-19 & Lawton, Okla & $98.30 \mathrm{~W} / 34.27 \mathrm{~N}$ & + & + \\
\hline 23 & OKCS-9, OKCS-40 & Frederick, Okla & $98.52 \mathrm{~W} / 34.16 \mathrm{~N}$ & + & + \\
\hline 24 & TXCS-13 & Graham, Tex & $98.41 \mathrm{~W} / 33.11 \mathrm{~N}$ & + & - \\
\hline 25 & TXCS-28 & Wellington, Tex & $100.27 \mathrm{~W} / 34.50 \mathrm{~N}$ & + & + \\
\hline 26 & TXCS-27 & Childress, Tex & $100.17 \mathrm{~W} / 34.43 \mathrm{~N}$ & + & + \\
\hline 27 & TXCS-17 & Paducah, Tex & $100.17 \mathrm{~W} / 34.15 \mathrm{~N}$ & + & + \\
\hline 28 & TXCS-20 & Guthrie, Tex & $100.14 \mathrm{~W} / 33.34 \mathrm{~N}$ & + & + \\
\hline 29 & TXCS-22 & Crowell, Tex & $99.35 \mathrm{~W} / 33.48 \mathrm{~N}$ & + & + \\
\hline 30 & TXCS-23 & Henrietta, Tex & $98.01 \mathrm{~W} / 33.38 \mathrm{~N}$ & + & + \\
\hline 31 & TXCS-15 & Electra, Tex & $98.54 \mathrm{~W} / 33.58 \mathrm{~N}$ & + & + \\
\hline 32 & TXCS-11 & Montague, Tex & $97.39 \mathrm{~W} / 33.39 \mathrm{~N}$ & + & + \\
\hline 33 & TXCS-30 & Montague, Tex & $97.37 \mathrm{~W} / 33.45 \mathrm{~N}$ & + & - \\
\hline 34 & TXCS-12 & Nocona, Tex & $97.57 \mathrm{~W} / 33.31 \mathrm{~N}$ & + & - \\
\hline 35 & TXCS-24 & Dallas, Tex & $97.07 \mathrm{~W} / 32.56 \mathrm{~N}$ & + & - \\
\hline
\end{tabular}

collected in 1989 from remnant prairies in the central United States (Hopkins et al. 1995). At each site, spikes were collected in a haphazard manner from plants located throughout the remnant site. Seed from all the spikes collected at a site were threshed and the seed was bulked. The bulked seed was given an accession number that identified both the accession and the collection site. The accessions represent a sample of the germplasm from each respective prairie. Seed from each accession was wet chilled for 3 weeks at $4.5^{\circ} \mathrm{C}$ and planted in the greenhouse into plastic seedling tubes or mini-pots in February 1990. After emergence, the seedlings were thinned to 1 seedling per tube. Seedlings of the accessions were transplanted into 3 field evaluation nurseries in the spring of 1990. The evaluation nurseries were located at Mead, Nebr., Ames, Iowa (Lat. $42.0^{\circ} \mathrm{N}$, Long. $93.6^{\circ} \mathrm{W}$ ), and West Lafayette, Ind (Lat $40.4^{\circ} \mathrm{N}$, Long. $86.9^{\circ} \mathrm{W}$ ). At each location, the seedlings of each accession were transplanted into single row evaluation plots. Rows and plants within rows were spaced $1.1 \mathrm{~m}$ apart. There were 10 plants per plot at Mead and Ames and 7 plants per plot at West Lafayette. There were 2 replications of each plot at the 3 locations.
The plots were evaluated for yield and forage quality in 1991 and 1992. In 1993, seed was harvested on a plot basis from the plants at the 3 locations. The seed was threshed, cleaned and bulked by accession. It was possible to maintain the genetic purity of each accession using this process because E. canadensis is a self-pollinated species (Jensen et al. 1990). Seed from 11 remnant prairie accessions were used to plant larger nurseries (Table 1, Sites 1-11). The accessions that were planted were those that had the most potential for use in pasture and prairie renovation based on the agronomic evaluations. Seedlings 
were propagated in the greenhouse using the procedures described above and transplanted into field nurseries at Mead in the spring of 1993. Each nursery consisted of 12 rows of 40 plants with rows and plants within rows spaced $1.1 \mathrm{~m}$ apart. The nurseries were managed for seed production. They were cultivated as needed for weed control by roto-tilling between plants and rows. Herbicides were also applied as needed for weed control. The nurseries were fertilized with $112 \mathrm{~kg} / \mathrm{ha} \mathrm{N}$ as $\mathrm{NH}_{4} \mathrm{NO}_{3}$ each spring. Seed of accessions from Oklahoma and Texas were collected in 1997 in the same manner as seed from the midwestern sites.

Three fresh tillers from at least 3 different plants were collected from each of the 11 established Elymus canadensis accessions at Mead and from the 2 prairie sites (Konza Prairie and Vinton Ranch) in Kansas and Nebraska in 1997. Late in the growing season, 3 additional flowering tillers were collected from each of the 2 prairie sites. Two plants and 3 seeds were examined for each Oklahoma and Texas accession. The midwestern plants and seeds were examined in a laboratory at Creighton University and the Oklahoma and Texas material was examined at the Noble Foundation, using similar procedures. The fresh tillers were taken to the laboratory and kept refrigerated in plastic bags until they could be screened for endophyte infection. We followed procedures outlined in Bacon and White (1994) to prepare and stain the tissue. Sectioned leaf sheath tissue from mature plants was placed within a $10 \%$ potassium hydroxide $(\mathrm{KOH})$ solution overnight to soften and clear the tissue. Leaf sheath tissue from younger plants was not treated with $\mathrm{KOH}$. An epidermal peel of the tissue was made and aniline blue stain was placed onto the tissue. The tissue was warmed for 1 minute and a light microscope was used to detect fungal hyphae, visible at $100 x$ power and confirmed at 400x. To screen seeds for the presence of the fungi, we placed seeds within a $1 \mathrm{~N}$ sodium hydroxide $(\mathrm{NaOH})$ solution to soften overnight. Then seeds were deglumed and placed within a warm aniline blue stain for one and a half minutes. The individual seed was then squashed for microscopic examination. Infection was detected through endophytic hyphae found within the aleurone layer of the seed. Seeds and tillers of Oklahoma and Texas accessions were examined at the Noble Foundation in 1998 using the same procedures given above.

We also checked each accession at Mead for the presence of stromata, the sexual form of fungal reproduction. Stromata appear on E. canadensis as a white external mat of hyphae, 3-10 cm long, and enveloping the flag leaf and culm (White and Bultman 1987, White and MorganJones 1987). All tillers from one-third of the plants from each accession were manually checked in July-August 1998 for the presence of stromata. Since E. canadensis in this region typically forms seed heads in July and August, the presence of stromata on mature tillers should be most evident during this time period.

The identity of the fungus in $E$. canadensis was assumed to be similar to the Neotyphodium endophytes in other $\mathrm{C}_{3}$ grasses, such as Festuca, and the same fungi as that previously described in Elymus species by White and Morgan-Jones (1987) and White and Bultman (1987). To provide some corroboration of fungal identity, we used a commercially available immunoblot assay to Neotyphodium (Agrinostics Ltd. Co.; 1501 Hickory Hill Drive; Watkinsville, Ga. 30677). The immunoblot produced a positive reaction to the $E$. canadensis endophyte in a random sample of tillers. In addition, we plated out the fungi in a random sample of seeds and greenhousegrown plants. Seeds and $5 \mathrm{~mm}$ sections of tillers were surface sterilized with $1.25 \%$ Clorox $(\mathrm{NaOCl})$ for $15 \mathrm{~min}$. and rinsed twice in sterile water, as described in Bacon and White (1994). Seed and tillers were placed in potato dextrose agar for 5 weeks and observed every 2-3 days. Seeds tended to be more contaminated with bacteria and other fungi than tillers; a more thorough decontamination protocol (e.g. Marshall et al. 1999) may be necessary for seeds. Two weeks after the initial plating, endophytic fungal hyphae grew out the ends of the tiller sections so that the entire mass was dumbbell-shaped. A swab of the endophytic fungus was placed on a fresh plate and in 2-3 weeks the fungal mass was $2-3 \mathrm{~cm}$ in diameter, white and cottony on the top and brown when viewed from the bottom of the plate. Samples of the fungi were examined via light microscopy and we noted the appearance of solitary phialides which appeared to have basal septa. Conidia were produced after 2-3 weeks of growth. These plating observations match those of White and Morgan-Jones (1987), and provide evidence that the $E$. candensis fungal endophyte should be placed in the Neotyphodium group described by Glenn et al. (1996).

\section{Results}

The fungal endophyte appeared in leaf sheaths as straight and sometimes wavy strands of hyphae that were typically much longer than an individual cell and never appeared to invade the cell (Fig. 2). In seeds, the hyphae appeared as dense mycelial mats. In 36 populations of Elymus canadensis from 8 states, the endophyte was found in every seed examined, and in at least 1 plant from all but 4 accessions (TXCS-12, TXCS-13, TXCS24, TXCS-30). Two accessions (OKCS26, OKCS-40) contained endophyte in only 1 of the 2 plants examined. In tall fescue, factors such as temperature, moisture, and time influence endophyte viability in seed (Williams et al. 1984). It is possible that viability of the endophyte, but not of the seed, was lost during seed storage in these accessions, resulting in presence of endophyte free plants. Despite thorough field observations, no evidence of stromata were found on the 11 accessions at Mead.

\section{Discussion}

Two other studies on the extent of endophyte infections in natural populations of Elymus (canadensis and virginicus) have been done. White (1987) examined herbarium specimens at the University of Texas, Texas A\&M, and Sul Ross State University. He found that 38 of 62 individuals $(61 \%)$ of $E$. canadensis and 21 out of 45 individuals (47\%) of E. virginicus were infected. He suggested that $1-10 \%$ of these individuals bears the stromata stage for potential sexual reproduction, while in the remaining infected individuals, the fungus reproduces asexually by growing into the seed (White and Bultman, 1987).

Clay and Leuchtmann (1989) performed the second study on the extent of endophyte infection in Elymus. They examined over 150 seed collections from E. virginicus and found that $72 \%$ of the seeds were endophyte infected. The seed was collected from the vicinity of Indiana University in south central Indiana. In these samples, both the Epichlö̈ (stromata present on culm) and Neotyphodium (no stromata development) types of fungal endophyte were detected.

No evidence of stromata was present in our field populations (Mead only). Stromata are most obvious when plants are fairly mature and the flowering culms are elongating to produce seed heads, a 

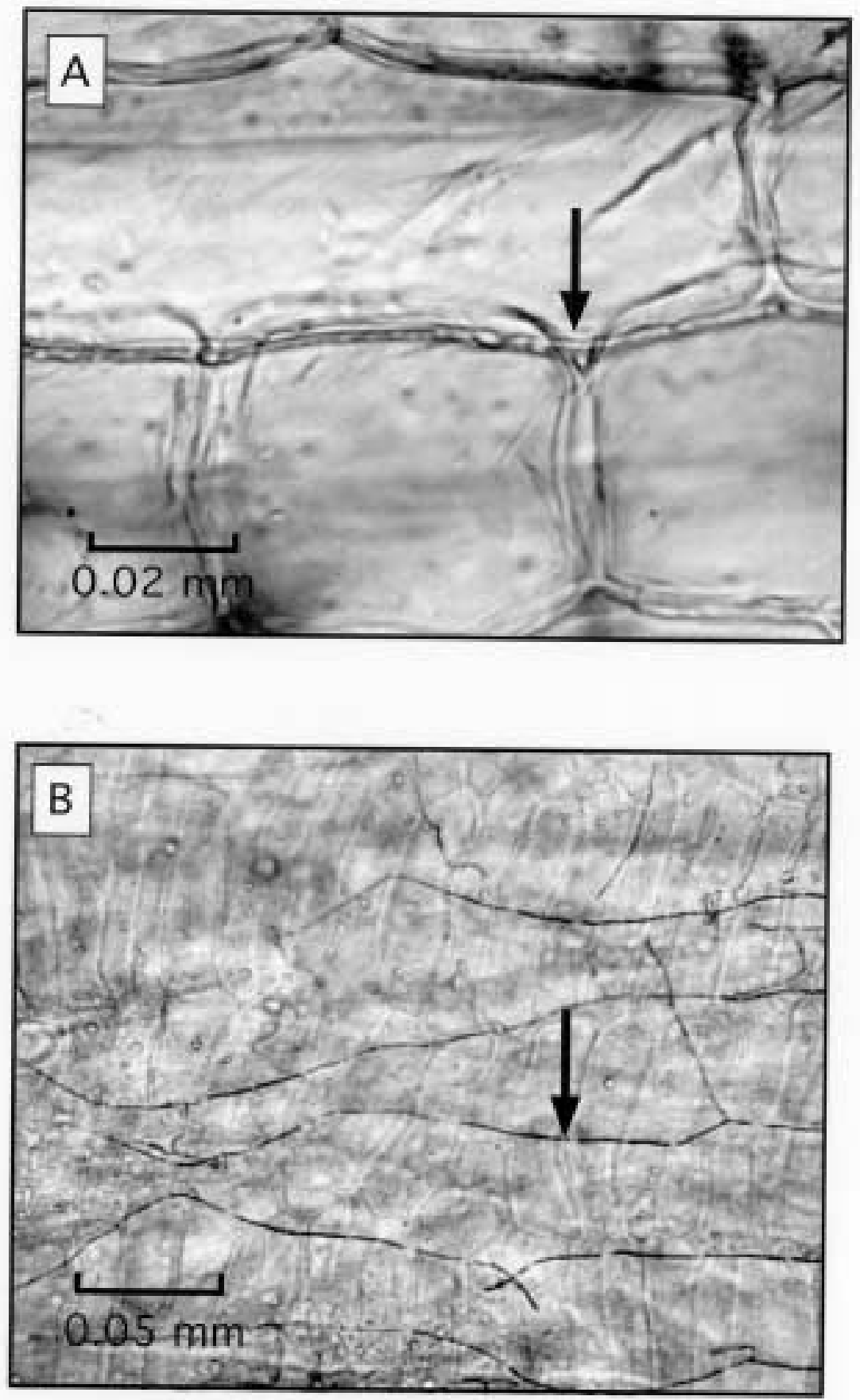

Fig. 2. Slides of endophytic fungal hyphae (arrows) in seed (A) and sheath tissue (B) from Elymus canadensis. Slides were cleared and stained with aniline blue solution.

stage that occurred in July-August at the Mead common garden site. In other studies of stromata occurrence, plants growing in wet areas were more likely to have stromata than plants in dry uplands (White, personal communication). Our common garden plants were generally large and vigorous, as they were maintained in cultivated plots with minimal competition. Thus, it is unlikely that these plants were lacking in resources, so the factors promoting stroma- ta development remain unclear. However, these results do clearly demonstrate that fungal transmission in E. canadensis, as in tall fescue and ryegrasses, occurs primarily via seed. Since the plant materials evaluated at Mead were 2 seed generations removed from the original plants in the remnant prairies, the presence of the endophyte in the plants demonstrates that in $E$. canadensis the endophyte is transmitted across generations via seed.
We found higher incidence of infection than did either White (1987) or Clay and Leuchtmann (1989), as our infection rate approached $100 \%$. Leuchtmann (1992) documented endophyte infection rates of 58 to $80 \%$ in native populations of Lolium perenne, L. multiflorum, Festuca arundinacea and $F$. pratensis in natural habitats in Europe. A number of studies have shown increases in the frequency of fungal endophytes in plant populations through time (e.g. Thompson et al. 1989, Shelby and Dalrymple, 1993). These increases are likely due to either 1) contagious spread of the fungus or 2) increased growth and fitness of the endophyte-infected plants due to greater herbivore resistance and competitive ability. Our results suggest that contagious spread is unlikely, since we observed no external, spore-producing stromata. Furthermore, our collections came primarily from relatively old habitats (e.g. virgin tallgrass prairie). The Oklahoma and Texas collections came from more disturbed sites than the midwestern accessions, but essentially no commercial varieties of E. canadensis are available in this region, so even the tissue from disturbed areas probably represents indigenous plants. Therefore, it seems possible that the fungal endophyte in Elymus canadensis increases plant fitness, through enhanced growth or herbivore resistance.

Preliminary tests of a few E. canadensis tillers suggest that ergot alkaloid levels are substantially less than the levels in endophyte-infected tall fescue (N. S. Hill, personal communication). The ergot alkaloids are one of the means by which mammalian herbivores are deterred in tall fescue, but at least 3 other alkaloidal compounds may be involved in herbivore deterrence in Neotyphodium-infected tissue (Siegel and Bush 1994, 1997). Other means by which the endophytic fungus could have positive effects on the plant are through increasing the growth and ability of the plant to cope with drought stress, as has been found in tall fescue (Arachevaleta et al. 1989). However, the possibility exists that Neotyphodium infection in E. canadensis, despite its widespread occurrence, does not confer drought tolerance or herbivore resistance on plants. Saikkonen et al. (1999) found no evidence that endophytes confer grazing resistance in native Arizona fescue populations and suggest endophytes in natural populations may be important in increasing pathogen resistance and competitive ability of adult plants rather than in mediating interactions with herbivores (Saikkonen et al. 1998). More experiments on the alkaloid levels, 
herbivore preference, pathogen resistance and drought response of endophyte-infected and uninfected plants of E. canadensis are necessary to elucidate the ecological significance of this widespread plant-fungal association.

\section{Literature Cited}

Arachevaleta, M., C.W. Bacon, C.S Hoveland, and D. E. Radcliffe. 1989. Effect of tall fescue endophyte on plant response to environmental stress. Agron. J. 81: 83-90.

Bacon, C.W. 1995. Toxic endophyte-infected tall fescue and range grasses: historic perspectives. J. Anim. Sci. 73:861-870.

Bacon, C.W. and J.F. White. 1994. Stains, media and procedures for analyzing endophytes, p. 47-56. In C.W. Bacon and J.F. White (eds.), Biotechnology of endophytic fungi of grasses. CRC Press, Boca Raton, Fla., USA.

Bacon, C.W., J.K. Porter, J.D. Robbins, and E.S. Luttrell. 1977. Epichloë typhina from toxic tall fescue grasses. Appl. and Environ. Microbiol. 34:576-581.

Ball, D.M., J.F. Pedersen, and G.D Lacefield. 1993. The tall-fescue endophyte. Amer. Sci. 81:370-380.

Belesky, D.P. and J.M. Fedders. 1995. Tall fescue development in response to Acremonium coenophialum and soil acidity. Crop Sci. 35: 529-533.

Clay, K. 1990. Fungal endophytes of grasses. Annu. Rev. of Ecol. and Systematics 21: 275-297

Clay, K. and A. Leuchtmann. 1989. Infection of woodland grasses by fungal endophytes Mycologia 81:805-811.

Clay, K., T.N. Hardy, and A.M. Hammond Jr. 1985. Fungal endophytes of grasses and their effects on an insect herbivore. Oecologia 66:1-6.
Funk, C.R., P.M. Halisky, M.C. Johnson, M.R. Siegel, A.V. Steward, S. Ahmad, R.H. Hurley, and I.C. Harvey. 1983. An endophytic fungus and resistance to sod webworms: association in Lolium perenne L. Biotechnology 1:189-191.

Glenn, A.E., C.W. Bacon, R. Price, R.T. Hanlin. 1996. Molecular phylogeny of Acremonium and its taxonomic implications. Mycologia 88:369-383.

Hopkins, A.A., K.P. Vogel, K.J. Moore, K.D. Johnson, and I.T. Carlson. 1995. Genotypic variability and genotype $\mathrm{x}$ environment interactions among switchgrass accessions from the midwestern USA. Crop Sci. 35:565-571.

Hoveland, C.S., S.P. Schmidt, C.C. King Jr., J.W. Odom, E.M. Clark, J.A. McGuire, L.A. Smith, H.W. Grimes, and J.L. Holliman. 1980. Association of Epichlö̈ typhina fungus and steer performance on tall fescue pasture. Agron. J. 72:1064-1065

Jensen, K.B., Y.F. Zhang, and D.R. Dewey. 1990. Mode of pollination of perennial species of the tribe Triticeae in relation to genomically defined genera. Can. J. Plant Sci. 70:215-225.

Leuchtmann, A. 1992. Systematics, distribution, and host specificity of grass endophytes. Natur. Toxins 1:150-162.

Marshall, D., B. Tunali, and L.R. Nelson. 1999. Occurrence of fungal endophytes in species of wild Triticum. Crop Sci. 39:1507-1512.

Saikkonen, K., S.H. Faeth, M. Helander, and T.J. Sullivan. 1998. Fungal endophytes: A continuum of interactions with host plants. Annu. Rev. Ecol. Syst. 29:319-343.

Saikkonen, K., M. Helander, S.H. Faeth, F. Schulthess, and D. Wilson. 1999. Endophyte-grass-herbivore interactions: the case of Neotyphodium endophytes in Arizona fescue populations. Oecologia 121: 411-420.
Schulthess, F.M. and S.H. Faeth. 1998. Distribution, abundances, and associations of the endophytic fungal community of Arizona fescue (Festuca arizonica). Mycologia 90:569-578.

Shelby, R.A. and L.W. Dalrymple. 1993. Long-term changes of endophyte infection in tall fescue stands. Grass and Forage Sci. 48: 356-361.

Siegel, M.R. and L.P. Bush. 1994. Importance of endophytes in forage grasses, a statement of problems and selection of endophytes. $p$. 135-150. In: C.W. Bacon and J.F. White (eds.), Biotechnology of endophytic fungi of grasses. CRC Press, Boca Raton, Fla., USA.

Siegel, M.R. and L.P. Bush. 1997. Toxin production in grass/endophyte associations. $\mathrm{p}$. 185-208. In: G.C. Carroll and P. Tudzynski (eds.), The Mycota. V. Plant Relationships, Part B. Springer-Verlag, Berlin.

Thompson, R.W., H.A. Freiborg, and B.B. Redick. 1989. Sampling intensity and timing for detecting Acremonium coenophialum incidence in tall fescue pastures. Agron. J. 81:966-971.

White, J.F., Jr. 1987. Widespread distribution of endophytes in the Poaceae. Plant Disease 71:340-342.

White, J.F., Jr. 1988. Endophyte-Host associations in forage grasses. XI. A proposal concerning origin and evolution. Mycologia 80: 442-446.

White, J.F., Jr. and T.L. Bultman. 1987. Endophyte-host associations in forage grasses. VIII. Heterothallism in Epichloë typhina. Amer. J. of Bot. 74:1716-1721.

White, J.F., Jr. and G. Morgan-Jones. 1987. Endophyte-host associations in forage grasses. IX. Concerning Acremonium typhinum, the anamorph of Epichlö̈ typhina. Mycotaxon. 29:489-500.

Williams, M.J., P.A. Backman, E.M. Clark, and J.F.White, Jr. 1984. Seed treatments for control of the tall fescue endophyte Acremonium coenophialum. Plant Disease 68:49-52. 